\title{
Damage pattern in historical centres: Isernia, an example in Southern Italy
}

\author{
Eliana Esposito $\left({ }^{1}\right)$, Letizia Laurelli $\left({ }^{2}\right)$ and Sabina Porfido $\left({ }^{1}\right)$ \\ ( $\left.{ }^{1}\right)$ Gruppo Nazionale Difesa dai Terremoti, C.N.R., Napoli, Italy \\ $\left(^{2}\right)$ Archivio di Stato, Isernia, Italy
}

\begin{abstract}
As regards the July 26, 1805 earthquake, a detailed study on the damage suffered by the town of Isernia has been carried out. As a first step in our research, we analyzed a manuscript of the time, in which describes damage to public buildings, churches and some notable houses caused by the earthquake. In order to identify such damaged sites, several archival sources and documents from 1816 to 1955 have been examined, on account of the remarkable changes in toponymy which occurred after 1861 and caused by the 1943 bombing. Moreover, due to the lack of cartography of the time, a 1875 map of the town has been used and compared with the land registry maps of a later period. The analysis of the 1805 damage pattern shows that the historical centre of the Isernia town is divided into three areas whose damage level is fairly different; such areas are respectively located in the southern, central and northern part of the town with an increase in damage from South to North.
\end{abstract}

Key words Southern Apennines - Isernia historical seismicity - damage pattern

\section{Introduction}

The town of Isernia (Southern Italy) and its districts was chosen as a sample to collect all the available and up to date information about past seismicity in areas of high seismic hazard; in fact the town has been hit by three of the strongest seismic events in the Southern Apennines.

The «Gruppo Nazionale Difesa dai Terremoti» (CNR) with the Isernia State Archive started to work to promote a detailed research on the historical seismicity of its district. Outstanding studies are emphasizing the importance of bibliographical and documentary sources in reporting and propagating the news of these seismic events. Such research has involved the Isernia, Campobasso and Naples State Archives. More and more detailed infor- mation has been obtained with the aim of working out:

- a map of damage caused by the 1805 seismic event in the town of Isernia;

- definition of the characteristic parameters of the earthquakes for the Molise province (Esposito et al., 1992).

\section{Historical seismicity}

The Molise region is located inside the Southern Apennines seismogenetic belt, and high intensity earthquakes have recurrently affected this area causing enormous destruction and the loss of thousands of human lives.

The historical seismicity of the Southern Apennines is characterized by the strongest earthquakes in Italy; the Molise region records three of them with epicentral intensity $I>\mathrm{X}$ MCS (table I).

The 1349, 1456 and 1805 earthquakes were the most dangerous events for the town of 
Table I. The most important earthquakes that took place in the Molise area and its surroundings are reported. The intensity is estimated according to the Mercalli-Cancani-Sieberg (MCS) scale.

\begin{tabular}{|c|c|c|c|c|c|c|}
\hline Year & Month & Day & Epicentral zone & $\begin{array}{l}\text { Epicentral } \\
\text { intensity }\end{array}$ & $\begin{array}{c}\text { Isernia } \\
\text { intensity }\end{array}$ & $\begin{array}{c}\text { References } \\
(*)\end{array}$ \\
\hline 346 & & & Sannio & & (damaged) & 1,2 \\
\hline 848 & 06 & & Campania-Molise & & (damaged) & 2,4 \\
\hline 990 & 10 & 25 & Conza C. (AV) & IX-X & (felt) & 3,4 \\
\hline 1231 & 06 & 01 & Montecassino (FR) & VIII-IX & & 4 \\
\hline 1293 & & & Boiano (CB) & VIII & & 4 \\
\hline 1349 & 09 & 09 & S. Elia F. (FR) & $\mathrm{X}$ & $\mathrm{X}$ & 4,5 \\
\hline 1456 & 12 & $5-30$ & Beneventano, Molise, Maiella & $\mathrm{X}$ & $\mathrm{X}$ & 4,6 \\
\hline 1688 & 06 & 05 & Campania & XI & VIII & 4,7 \\
\hline 1702 & 03 & 14 & Benevento & $\mathrm{X}$ & (felt) & 4,8 \\
\hline 1706 & 11 & 03 & Maiella & IX-X & (damaged) & 4 \\
\hline 1712 & 05 & 08 & Campobasso & VI-VII & (felt) & 4 \\
\hline 1805 & 07 & 26 & Frosolone (IS) & XI & IX & 4,9 \\
\hline 1825 & 10 & 27 & Monteroduni (IS) & VI & (damaged) & 4 \\
\hline 1873 & 12 & 13 & Venafro (IS) & VII & (felt) & 4 \\
\hline 1875 & 12 & 06 & S. Marco in L. (FG) & VIII & (felt) & 4 \\
\hline 1885 & 12 & 26 & Campobasso & VII-VIII & (felt) & 4 \\
\hline 1913 & 10 & 04 & Vinchiaturo (CB) & VIII & $\mathrm{V}$ & 4,10 \\
\hline 1914 & 12 & 19 & S. Agapito (IS) & VII & VII & 4 \\
\hline 1915 & 01 & 13 & Avezzano (AQ) & XI & VI & 4,10 \\
\hline 1930 & 07 & 23 & Irpinia & $\mathrm{X}$ & V & 4,10 \\
\hline 1962 & 08 & 21 & Irpinia-Sannio & IX & $\mathrm{V}$ & 4,10 \\
\hline 1980 & 11 & 23 & Irpinia-Lucania & IX-X & V & 4,11 \\
\hline 1984 & 05 & 07 & Alfedena (AQ) & VII & VII & 12 \\
\hline
\end{tabular}

(*) 1: Baratta, 1901; 2: Guidoboni (Editor), 1989; 3: Molin, 1985; 4: Stucchi et al., 1993; 5: Molin and Guidoboni, 1989; 6: Meletti et al., 1988; 7: Serva, 1985; 8: Molin and Serva, 1985; 9: Esposito et al., 1987; 10: Spadea et al., 1985; 11: Postpischl et al., 1985; 12: Esposito et al., 1988.

Isernia that was completely destroyed three times. The 1349 earthquake affected mainly the Abruzzo and Molise regions (Molin and Guidoboni, 1989; fig. 1), disastrous above all for the city of L'Aquila, the Isernia district was strongly hit and the city of Isernia was destroyed: «diruit et subvertit Ecclesiam Iserniensem, et generaliter omnia aedificia civita- tis Isernie a minori usque ad maius; itaque nullum omnino remansit, vel quod esset totaliter destructum, vel pro maiori dirutum» (Viti, 1972).

Based on the reconstruction of historical earthquakes up to now carried out all over Italy, the December 1456 earthquake seems to be the strongest in terms of extension of the 
shaken area as well the number of victims (fig. 2).

The isoseismal map of the event shows that the epicentral area is characterized by several localities with intesity $I=\mathrm{X}$ MCS, six of them are located inside the Molise area: Isernia, Macchiagodena, Frosolone, Casalciprano, S. Polomatese and Vinchiaturo.

The town of Isernia was completely destroyed: «Civitas nostra Iserniae totaliter fuit ruinata et conquassata, et omnia aedificia a majore usque ad minus projecta in terram» (Figliuolo, 1988).
The 26 July 1805 event, known as the St. Anna earthquake, hit mainly the Molise and Campania regions, the number of deaths was about 6000. The maximum damage was in the village of Frosolone (Isernia district) that was razed to the ground (Esposito et al., 1987).

As regards recent seismicity, the 7-11 May 1984 and the January 1986 seismic sequences were the most interesting in the area; the first one was located inside the National Park of Abruzzo, while the macroseismic epicenter was located in the village of Alfedena (L'Aquila district) (Esposito et al., 1988;

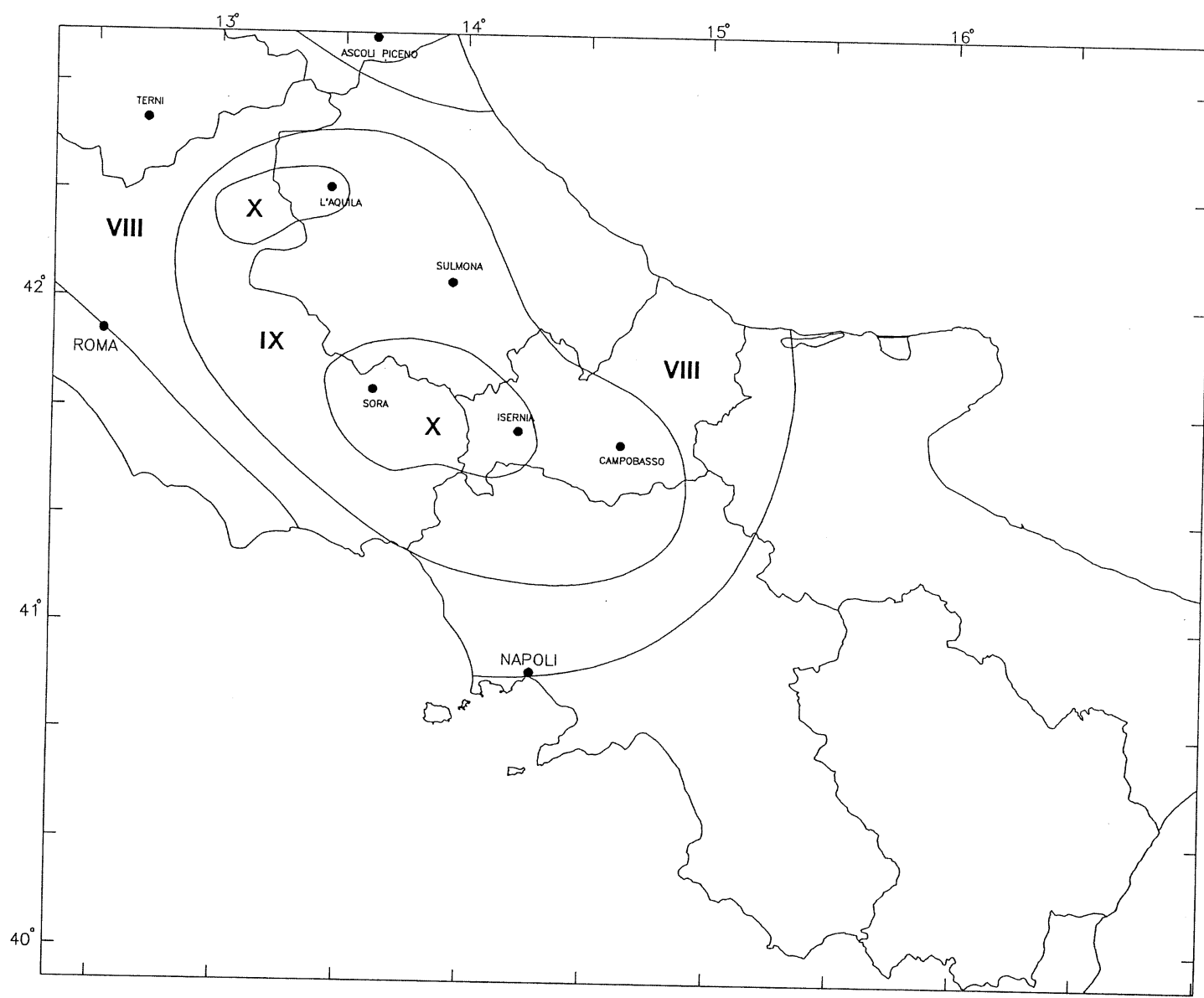

Fig. 1. Isoseismal map of the September 1349 earthquake. The map shows two epicentral areas located respectively around the city of L'Aquila and around the towns of Isernia and Sora. The intensity in Isernia reached the X degree on the MCS scale (modified from Molin and Guidoboni, 1989). 


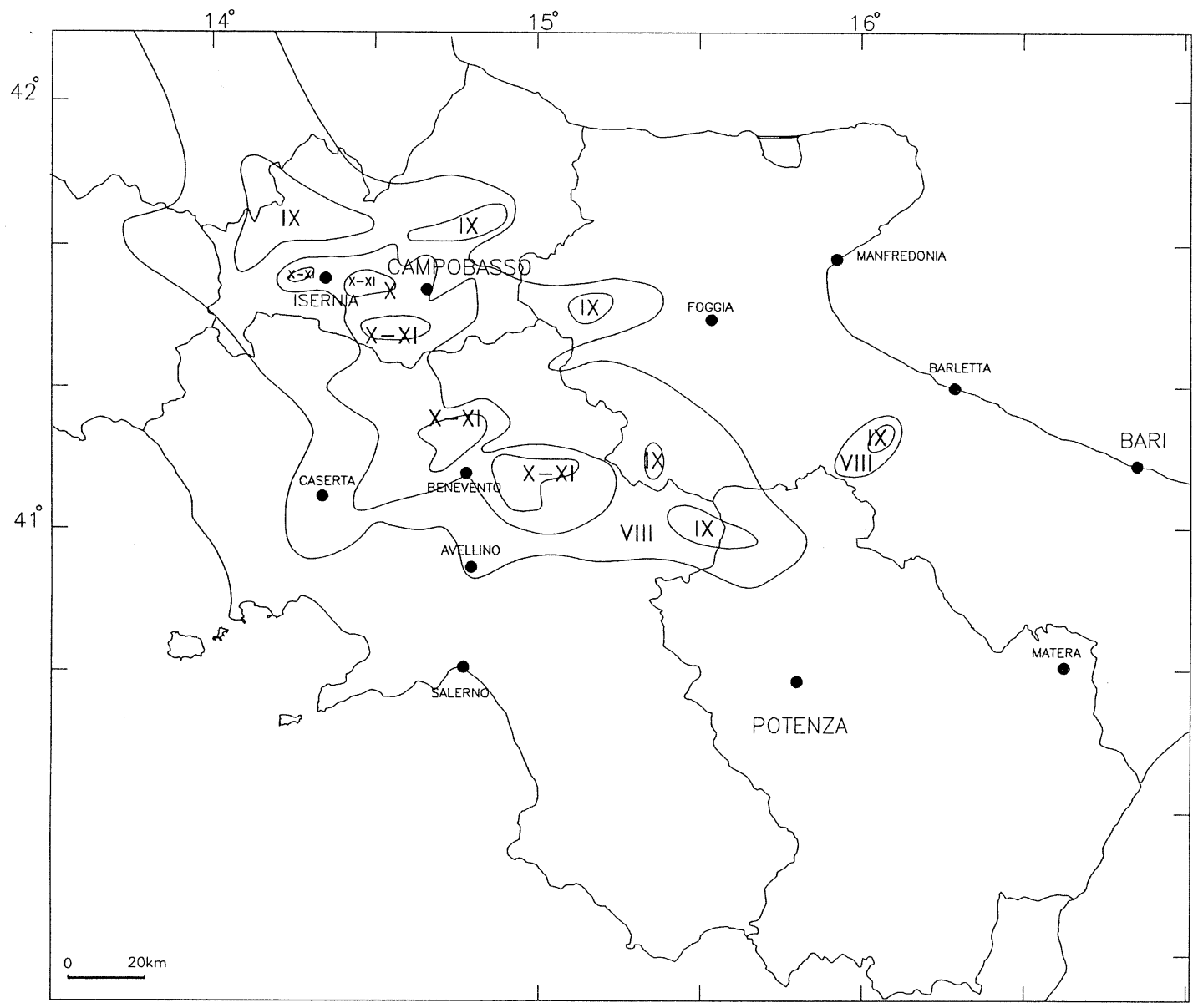

Fig. 2. Isoseismal map of the December 1456 Southern Italy earthquake. The shaken area includes most of Central and Southern Italy, the epicentral areas $(I=\mathrm{X}$ MCS) are mostly located in the Molise region (modified from Meletti et al., 1988).

fig. 3); the second one was located in a small area NE of Isernia (Alessio et al., 1987).

\section{The July 26,1805 earthquake}

The July 26, 1805 earthquake is one of the most catastrophic to have occurred in Italy. Felt by the whole of Southern Italy, this earthquake caused considerable hydrogeological and geological devastation, such as turbidity, and variations in the level and flow of water, fractures, landslides and soil liquefactions (Esposito et al., 1989; Porfido et al., 1991).

The macroseismic historical reconstruction of the earthquake is mainly based on the original unknown and contemporary documents and maps found at Naples, Campobasso and Isernia's State Archives.

These documents are mostly letters between a tax lawyer, the royal plenipotentiary in the Molise area, and a local administrator. 


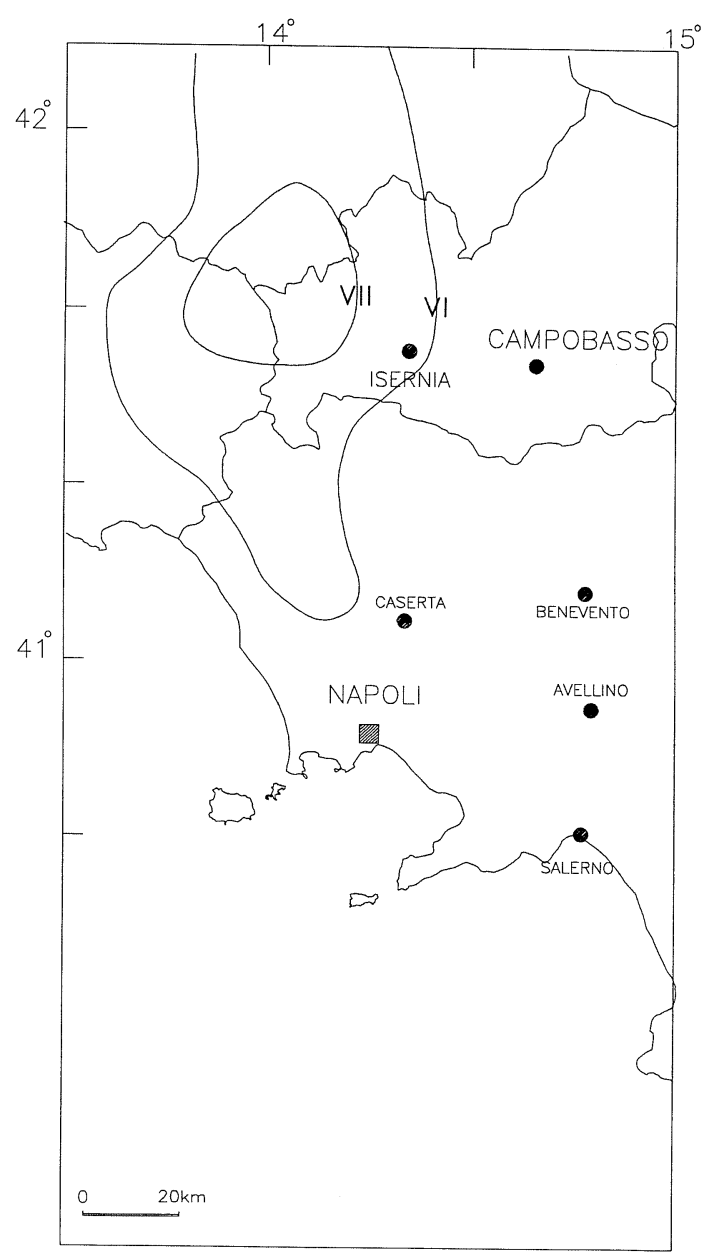

Fig. 3. Macroseismic field of the 7-11 May 1984 events. The picture shows just the epicentral area of the events, where it is possible to note a length of about $40 \mathrm{~km}$, with effects of VII MCS and general lengthening towards $\mathrm{N}-\mathrm{S}$ (modified from Esposito et al., 1988).

The documents include initial accounts of the earthquake, as well as detailed later damage assessments. The initial information relates to letters sent from the local authorities to the tax lawyer within minutes of the main shock; they indicate the level of public office held by the writer, emphasize the effects on buildings and public order and touch immediate accounts.
The maximum damage was in Frosolone (Province of Isernia), where the intensity reached XI on the MCS scale; using data from 241 localities, it has been possible to draw an isoseismal map (fig. 4) that includes the area from intensity X to VII MCS (Esposito et al., 1987, 1991).

\section{The Isernia earthquake}

The July 26, 1805 earthquake caused heavy damage to the town buildings, killing hundreds of people.

The first accounts of the event date back to July 27, the day after the main shock, when the local authorities wrote to Ferdinando IV, king of Naples: «jeri sera 26 dell'andante luglio, verso le due e mezza della notte cadde tutta la città da tremuoto, a tal che buona parte de. cittadini sotterrati vivi dalla rovina ebbe a pigliar ricovero nell'aperta campagna ... Isernia, Maestà, non è più Isernia, e le fabbriche tutte o son cadute, o stanno per cadere al suolo...» (early this morning July 26, at about half past two the whole city was destroyed because of the earthquake; most of the inhabitants took shelter in the country... Isernia, your Majesty, is not Isernia any more. Almost all buildings have collapsed, or are about to collapse), (Naples State Archive, Ministery of Finance, fs. 2478).

After a few days, on August 2, Gabriele Giannoccoli, president and tax lawyer of the Regia Camera of Sommaria, entrusted by the King to survey and repair the damage caused by the earthquake in the provinces of «Principato Ultra» and «Capitanata e Contado di Molise» addressed a detailed report to the Segretario di Stato di Azienda in Naples, providing a detailed description of the event, and also assessing damages and victims. He wrote that in Isernia «un numero di circa 6000 anime ne ha sofferta la perdita di circa 2000; ed una sola decima parte delle fabbriche esiste in piedi, ma che minaccia anche di rovinare... Essendo interamente intercettata la comunicazione interna del paese, in mezzo del quale era il corso della Strada Regia, è necessario che sollecitamente sia ricostruita una strada dal lato esterno...» 


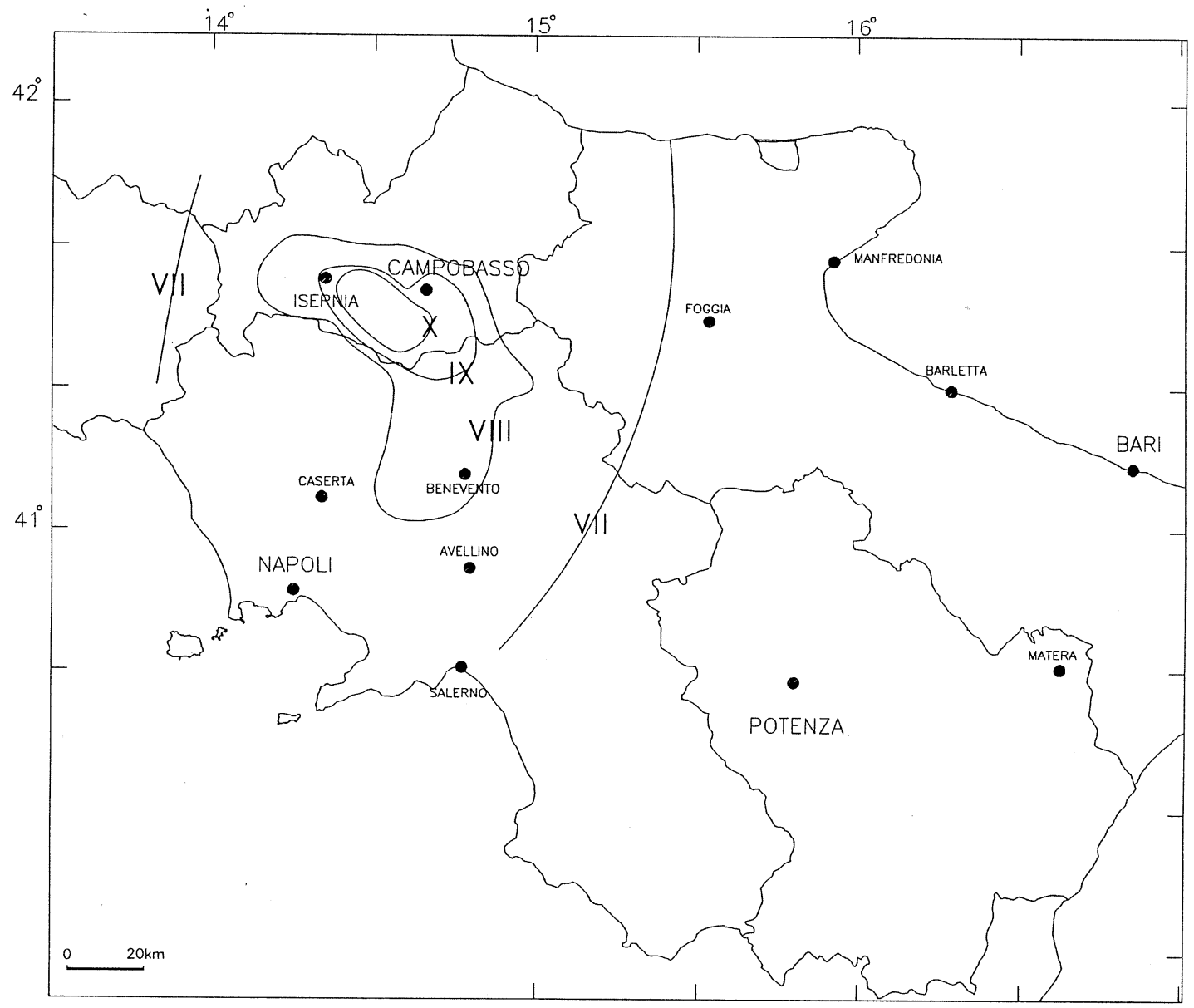

Fig. 4. Isoseismal map of the 26th July 1805 earthquake. The isoseismal lines indicate lengthening in the direction of the Apennine chain. In particular, a lobe of amplification in the direction of the TaburnoCamposauro massif and high perceptibility in the direction of the province of Naples are evident in the VIII MCS zone. Moreover, the highest values of the isosists show a marked attenuation towards SW coinciding with the Matese mountains (after Esposito et al., 1987).

(2000 people out of 6000 have died; only one tenth of the buildings are still standing, but are about to collapse; the only inner road being obstructed by ruins, it is necessary to build an outer road as soon as possible), (Naples State Archive, Ministery of Finance, fs. 2478).

A few days after the earthquake, Gabriele Pepe (1806) as an eye witness, in the «Ragguaglio Istorico-Fisico del tremuoto accaduto nel Regno di Napoli la sera de' 26 luglio 1805», reports that «In Isernia si osserva di più un'altra specie d'irregolarità. Questa Città non ha che una sola strada nel mezzo ed una serie di edifizj lateralmente. Un tal grottesca costruzione le dà più di un miglio di lunghezza, e picciolissima larghezza. Il Tremuoto rovinò una mettà della Città solamente e propriamente quella che si eleva verso l'Oriente, ossia la più prossima agli Appennini» (In Isernia a peculiar irregularity can be observed. There is 
only one road crossing the town and a series of buildings on the sides of it. This road is more than one mile long, but it is very narrow. The earthquake has destroyed only half of the town, the one rising towards east, that is, the part that is nearest the Apennines).

Giuseppe Capozzi (1834), in the «Memoria sul tremuoto avvenuto nel Contado di Molise nella sera de' 26 Luglio dell'anno 1805», found a certain irregularity in the distribution of damages: «Isernia è caduta in una maniera curiosa. Per quella parte, che guarda il mezzogiorno, e si dirigge a Boiano, quantunque sia la più alta, è interamente inabissata, per la parte poi, che guarda il Settentrione, ancorché più bassa, conserva ancora qualche cosa in piedi» (Isernia has been damaged by the earthquake in a strange way. The highest part, towards Boiano, is completely destroyed, while in the lowest part some buildings have stood up).

Giuseppe Saverio Poli (1806), commanderin-chief of the Real Accademia Militare who was constantly in contact with the Duke of Ascoli, General Superintendent of Police, in his «Memoria» on the 1805 earthquake emphasizes the damages suffered by the town, which «ha sofferto disastri orribili: può dirsi esser stata ella per metà adeguata al suolo, e nel rimanente desolata... morti 1000, feriti 50» (The town has suffered terrible damage... Almost half of it has been destroyed, and the rest is heavily damaged... 1000 dead, 50 injured).

All the sorces examined, both archival and bibliographical, contribute to the assessment of the damage suffered by the town of Isernia, and most of them seem to suggest an anomalous distribution of effects. These concentrate mainly in the highest part of the town, while in the southern area the earthquake damaged mostly churches, monasteries and larger buildings rather than private houses.

Concerning this, the same Pepe (1806) testifies that «circa $i$ guasti prodotti dal Tremuoto, $i$ quali furon più grandi né grandi edifizj che sogliono ordinariamente esser più elevati dagli altri; la quale considerazione combinata con quella dedotta dalla di loro solidità non lascia motivo alcuno da meravigliarsi nell'essersi osservato che i Monasteri, le Chiese, i Palazzi
Baronali, e tutte le grandi fabriche della Contea soffriron un danno maggiore di tutte le altre, egualmente che nella Capitale $i$ Castelli, $i$ Conventi, gli edifizj pubblici, e le grandi Chiese furon in proporzione più danneggiate degli altri edifizj» (The damage caused by the earthquake, has been proportionally heavier for large buildings, which are also higher. This phenomenon is not surprising as regards monasteries, churches, baronial houses both in the country and the capital city, Naples).

\section{The «memoria» of Fortini for the recon- struction of the 1805 Isernia earthquake}

The assessment of damages caused by the July 26, 1805 earthquake in Isernia is based on the «memoria» of Pasquale Fortini, entitled «Delle cause de' terremoti e loro effetti. Danni di quelli sofferti dalla città di Isernia fino a quello de' 26 luglio 1805», edited by Titina Sardelli for Ed. Marinelli, in 1984.

The original manuscript, kept by the Milano-Veneziale family of Isernia, was written by Pasquale Fortini, lawyer and landowner, who lived between the late 18th and early 19th century in Isernia, where he died in July 1819 , at his house in strada Nunziata. The document is divided into 11 chapters.

In chapter 1 the author explains the causes of earthquakes following the theory of «foci», currently accepted until the 18 th century according to which earthquakes were believed to be caused by masses of fire enclosed in the bowels of the earth.

In chapter 2 , after examining the phenomena preceding and accompanying the seismic events, he emphasizes, in chapter 3 , the «sistema fisico moderno», considering seismic phenomena similar to electrical phenomena, therefore caused by «rottura di equilibrio tra il fluido elettrico, che regna nell'atmosfera, $e$ quello, ch'è proprio alla massa della terra» (breaking of balance between the electric fluid in the atmosphere and that belonging to the mass of the earth).

In chapter 4 the author provides a lively and detailed description of the damage of the 1805 earthquake to churches and houses of notable 
families of Isernia followed by a similarly detailed account of the shocks felt in Isernia from St. Anna's day until May 1806. In chapter 5 the author recollects the phenomena which preceded, accompanied and followed the earthquake in Isernia and other areas of Contado di Molise, while chapter 6 is an account of the damage caused by the seism in some areas of the Contado, as well as an estimation of the number of victims. According to Fortini, these would be altogether 6263, in accordance with the reports provided by his «locali amici» (local friends).

In chapter 7 we find a recollection of the most disastrous earthquakes to have occurred in Isernia in different periods: from the 847 event to the 1349 and 1456 ones, described in a parchment which is said to be stored in the Cathedral archive, reporting the almost total collapse of the town. In chapter 8 the Author describes the place and the nature of the soil of Isernia, pointing out the presence and usefulness of waters «sulfuree, alluminose e ferrate» (containing sulphur, aluminium and iron), found abundantly in the soil, and known since ancient times.

Chapter 9 is devoted to the destruction caused to the city by wars and invasions. Fortini takes these events as a starting point for giving suggestions on the possible way of reconstructing Isernia, with the greatest care on the part of both citizens and government.

The following is an extremely interesting chapter on the actions undertaken by the Borboni government in the Contado di Molise following the 1805 earthquake.

Here the author shows himself to be reliable, since the data he relates find full confirmation in the documentary material on the earthquake kept in the State Archive of Naples in the Ministery of Finance fund.

Finally, chapter 11 reports the «preghiera» (plea) of the citizens to Giuseppe Bonaparte, new king of Naples, the people confide in the king's benevolence and generosity «per risorgere dalla desolazione sofferta» (to rise up from the desolation suffered).

This last reference allows an approximate dating of the manuscript, taking into account the fact that Giuseppe Bonaparte was king of
Naples until the first half of 1808. Therefore we can agree with Sardelli, in that «l'opuscolo che l'Autore, a partire dal capitolo IV, incominciò a scrivere a mo' di diario il giorno stesso del terremoto e continuò fino al maggio 1806, fu portato a termine nel periodo successivo alla visita di Giuseppe Bonaparte nel Molise e alla sua sosta ad Isernia nel settembre 1807» (the booklet that the author, starting from chapter IV, began to write as a diary on the very day of the earthquake and kept on writing until May 1806, was completed after Giuseppe Bonaparte visited Molise and stayed in Isernia in September 1807).

The manuscript can therefore be considered a coeval source, moreover presenting itself mostly as a diary, the private source par excellence. The testimonial value of a diarist like Fortini is based on the fact that his knowledge of the reported events is direct and he had no interest in consciously distorting data.

His subjective and «local» point of view, far from being his limitation, is actually his major merit for the reconstruction of a phenomenon, like the earthquake, which occurred in the area under investigation in his «memoria». Consequently, we focussed our attention on chapter 4 , where the author provides a detailed estimate of damage by the Isernia 1805 earthquake.

The description of damage mainly regards the places of worship and the houses belonging to the notables of Isernia: in several cases the heavily damaged parts and the state of habitability are emphasized.

The most detailed information therefore concerns the best building, generally located along the main street, which is defined as «pubblica strada, o sia piazza» (the public road or square) which that is how the elderly still call today's corso Marcelli. And it is along this way, starting from «dall'entrata della via di Napoli» (the entry to Naples street) in the lowest part of the town, that the Fortini description develops, touching both sides of the same street and the adjacent lanes.

From the very beginning of his description, the author stresses the division of the city into two parts, pointing out the presence of the 
cathedral bell-tower placed almost half-way along the main street.

This division is also useful to define areas affected by different degrees of damage; first, the area including the convent of Frati Cappuccini and the bell-tower is described; a second description starts from the bell-tower and develops along the «strada degli Abruzzi», coinciding in this part with the town's main street.

It is this second description that give us a clear idea of the seriousness of the event: «... Lugubre vieppiù, non menocché orribile scena si apre agli occhi dello Spettatore nel rimirare la parte superiore dell'atterrata Città. Ogni anima sensibile ed umana ad un tale funesto spettacolo non può fare ammeno di non prorompere in compassionevoli lagrime. Dal punto del suddetto Campanile tirando in su verso gli Abruzzi, tutto quas'il resto della Città, che ne formava la maggior parte l'è un ammasso di pietre, vedendosi solamente alcuni spezzoni di mura tutte fracassate, le quali maggiormente feriscono gli occhi dell'osservatore...» (a dismal scene appears to the onlooker as he observes the highest part of the town, completely crushed down. Any sensitive human soul cannot help being upset at such a sight. From the bell-tower towards Abruzzi, all this part of the town which is also the largest part, is a pile of ruins, where only a few remains of shattered walls can be seen, which deeply affect the observer's eye).

An irregular distribution of damage is therefore evident, and the area which seems to have suffered heavily is the north-east area, topographically the highest part of Isernia.

\section{Pattern of damage. Methodology}

The reassembling of damage suffered by the city has required the definition of a methodology in order to map the sites described by Fortini. This identification presented some difficulties, since most of the families mentioned no longer exist.

Moreover, the historical town centre has been irreparably destroyed by the 1943 bombings and by the subsequent demolition which have undoubtedly transformed the original layout of the city.

It was therefore necessary to find some coeval documentation, or, at least, near to the event. The most obvious references were the contemporary Napoleonic cadastral registers of Isernia, stored in the city State Archive. This cadastral survey, compiled according to the real Decreto August 12, 1809 was to replace the outdated register created by Carlo di Borbone in 1740, better know as «onciario», after the monetary unit used for the estimation of property.

The French register was said to by temporary, having only a descriptive value, and having to be replaced by a «geometrical» one $\left({ }^{1}\right)$. Its compilation was made on the basis of the so called «stati di sezioni» (section states), types of registers in which the municipal land appeared to be partitioned into sections, each distinguished by a letter of the alphabet. «Per ogni sezione, cominciando da est verso ovest, si dovevano annotare le proprietà esistenti, designando nome, cognome, domicilio del proprietario, la natura dei beni» (for each section, starting from east to west, the existing properties had to be noted, recording the name, surname and address of the owner and type of property), (Stella, 1989).

The «Stato di Sezioni» (section state) concerning the municipality of Isernia proved fundamental for our study. In Section I, called «l'Abitato» (the dwelling) the owner's name for each house is reported, together with the indication of street or area, features, extension and income, following a prearranged procedure.

It has been verified that such survey begins from what is still called Largo Cappuccini, in the southern area of the town, and then it goes back up today's corso Marcelli along the eastern right side, until the northern limit of the built-up area in the Fiera locality (today's Villa Comunale). Then it goes down again along the same route along the western left side.

This part of «Stato di Sezioni» (the section state) proved to be a circumstantial description of the urban conglomeration of Isernia during the early Restoration, since the French land registry survey had been established in 1816, when the town still showed the consequences 
of the 1805 earthquakes as testified by the various «Siti diruti» (ruined places) and «case in fabrica» (houses being built) reported in the register.

Nevertheless, this valuable documentary source had to be supported by cartographic elements, which were missing for the early 19 th century. Neither could we make use of the temporary land registry mentioned above, as this was only a descriptive document, lacking therefore any planimetry.

It was then necessary, without coeval cartography, to use a plan of Isernia (1875 yr, scale 1: 1000), found at the local Revenue Office, and kept today in the Isernia State Archive. We also used later cadastral maps, stored in the same Archive. The utilization of the revenue Office plan proved to be difficult, not only because it had been drawn up 70 years after the earthquake, but mainly because of toponomastic changes which occurred in the years following the «Unità d'Italia» (unification of Italy) and therefore not comparable to the description of the «Stato di Sezioni» (section state).

These changes subsequently became the object of further study on additional sources available in the Archive Institute of Isernia, such as the Deeds of civil status, Cadastral funds, the series of «Atti diversi» (miscellaneous acts) of the Law Court of Isernia, the «Atti amministrativi» (administrative acts) of the Subprefecture of Isernia.

All these sources, together with other documents belonging to the Isernia historical Archive (stored today in the Biblioteca Comunale M. Romano) have been examined and analyzed; in order to establish a reliable identification of the sites described by Fortini.

This task became rather complex with the discovery that the plan provided by the Ufficio
Tecnico Erariale (UTE) found confirmation in the registers of the old "Catasto Fabbricati», also stored in the Isernia State Archive and deposited at the time by the local Ufficio Imposte Dirette. This land registry, which came into storage in 1877 , according to the law dated 11th August 1870, was effective until the Nuovo Catasto Edilizio Urbano was established in 1962. The first ledgers of Isernia concerned the town lay-out, and in every «partita catastale» the single parcels of building were identified not only by toponymic location and description in terms of floors and rooms, but also by a reference number, accompanied by the wording «della mappa originale» (of the original map).

On the basis of the information acquired while carrying out this study we have ascertained that the plan found at UTE had to be the one originally attached to the registers of Catasto Fabbricati, coming from the Ufficio Imposte Dirette of Isernia. The differences in the location of sources could be explained by the different administrative organization of the offices which were in charge of land registry operations from the years after the Unification of Italy onwards.

We then revised the work on a plan, attributing to each number the respective «ditta proprietaria» (ower firm) 1877.

It was impossible to identify all the parcels described in the asset of the first four registers, two of them being blank (ledgers 1 and 3 exactly), probably because they were reconstructed after being damaged in wartime.

In order to make up for the lack of data in the blank registers, a further analysis of ledgers 5-7 was carried out. These ledgers included the land registry variations immediately following the establishment of the land registries.

Fig. 5. Damage map of the 1805 earthquake in the historical centre of Isernia. The colours indicate the various levels of damage; the letters indicate the monumental buildings, while the numbers are private dwellings. 


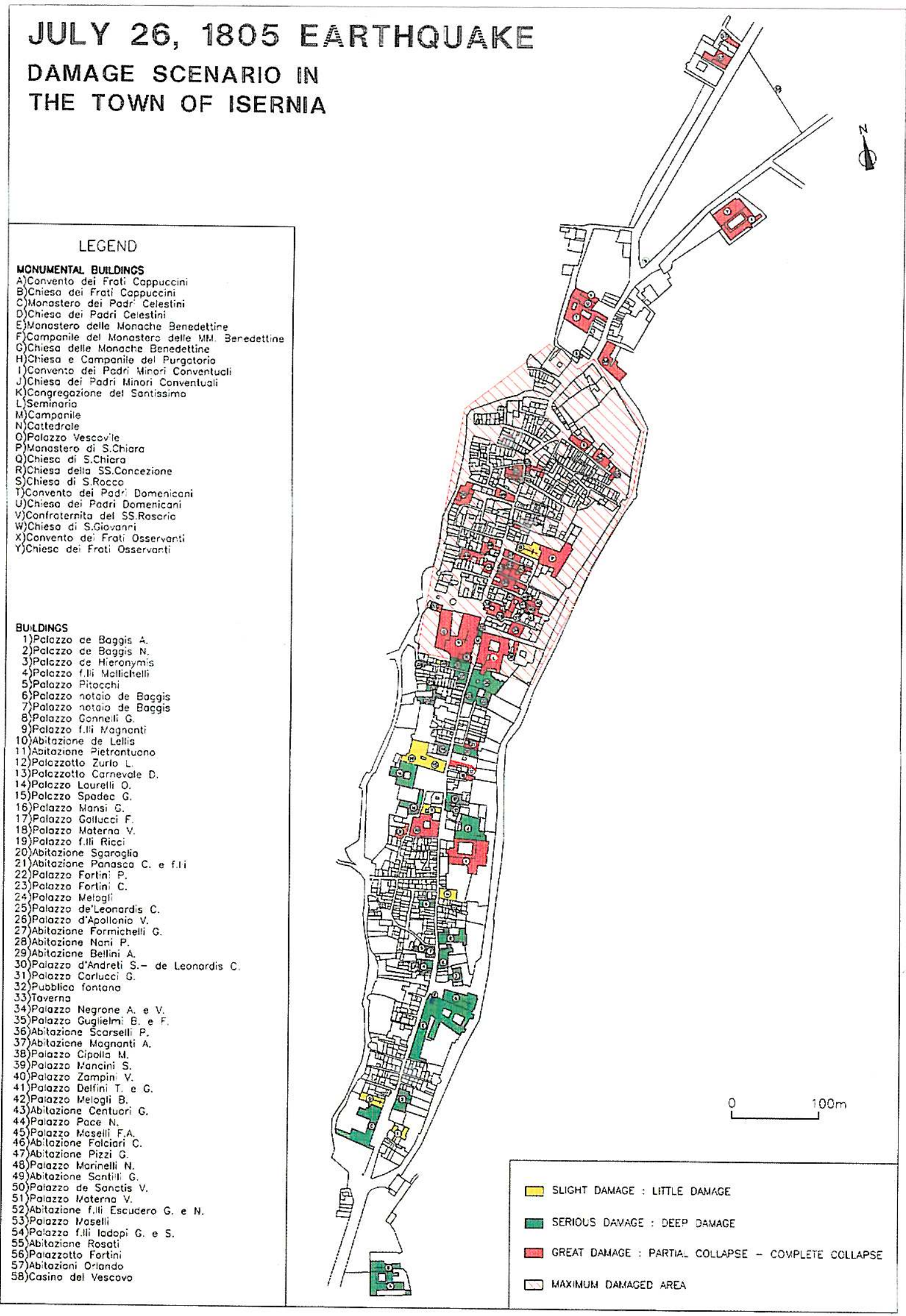


As a whole, this meticulous work identified with greatest accuracy the buildings described by Fortini 70 years earlier, thus reducing the margin of error, since the utilized source was incomplete and not coeval, as well as later than the seismic event under examination. On the contrary, the source seemed to confirm the few transfers of property which occurred in the course of the 19th century, at least for the houses of the notable families of Isernia, which had been the main concern of Fortini in his description of the 1805 earthquake.

\section{Damage classification and distribution}

The classification of damage suffered by the buildings of Isernia was carried out by means of the expressions and terms used by Fortini. This analysis was possible thanks to the fact that the author describes damage by recurring adjectives and adverbs, which define increasing levels of damage.

The three classes, corresponding to increasing damage, are the following:

Minor damage - Slight damage, surface cracks defined by the adjectives: «leggiermente lesa», «picciola parte patita».

Serious damage - Cracks, heavy cracks defined by the adjectives: «lesionato ma non tanto», «tutta lesionata».

Heavy damage, partial and total collapse Heavy cracks, partial and total collapse defined by the adjective: «moltissimo danneggiato», «in parte gittato a terra», «totalmente rovinato».

The list of terms used by Fortini and included in the damage classification is then

Fig. 6. The 26th July 1805 earthquake, schematic map of the damage in the historical centre of Isernia. The rectangles indicate the areas with different seismic response. Note the spreading of the damage from South to North with a concentration in the northern part of the town.

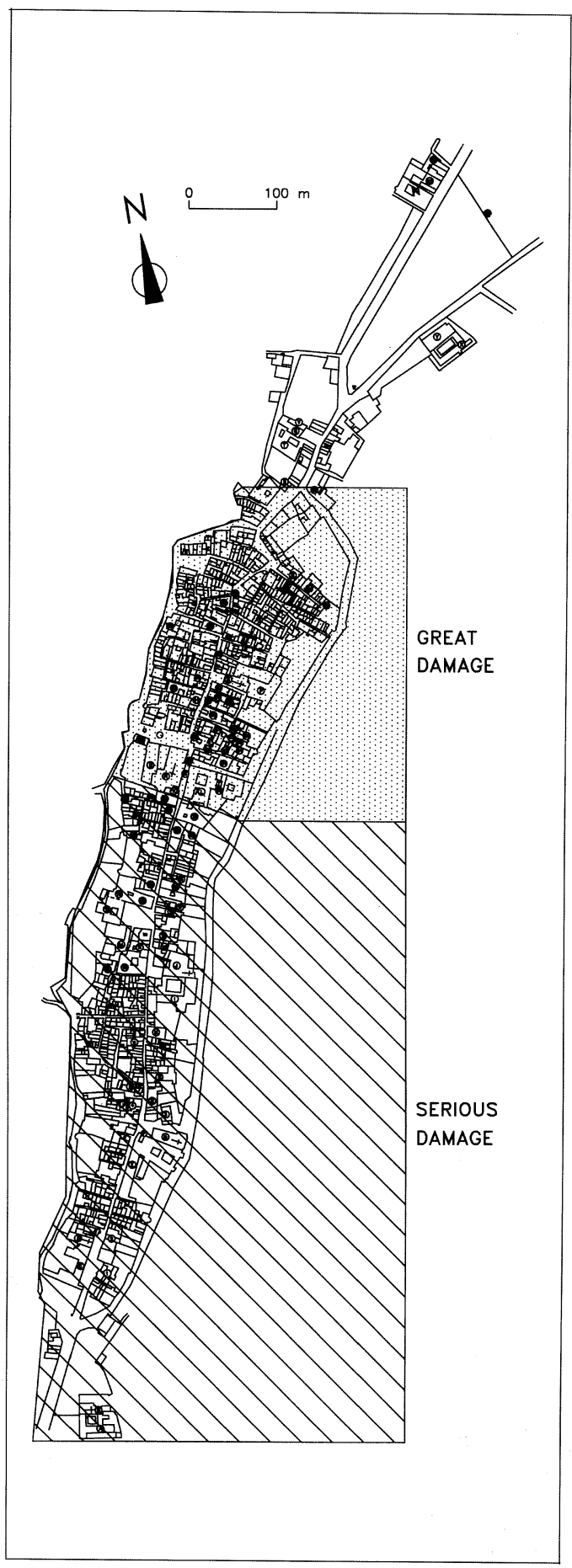


quoted. Numbers and letters refer to the localization of buildings on the enclosed plan of the pattern of damages (see fig. 5 and Appendix).

It is evident that this type of damage appears to be generally scarce, since only a few buildings are shown on the map (coloured in yellow). However, many land registry parts, localized in the south-western area and uncoloured, are likely to have suffered this type of damage. The lack of direct information on this area is presumably due to the absence of the heaviest damage.

The church of Santa Chiara is the only slightly damaged building located in the northern area.

The distribution of serious damage is homogeneous in the central-southern area of the town (coloured in green).

A slight increase is evident as we approach the northern area. This type of damage mainly affects large buildings, such as the church and convent of Frati Cappuccini, the monastery of Monache Benedettine, the church of Minori Conventuali and Palazzo Laurelli.

The heavily damaged area (coloured in red and dotted area) is mainly concentrated in the northern part of the town, extending from piazza Mercato to largo S. Rocco (today's piazza Carducci).

The Cattedrale, the Seminario and the convent of Minori Conventuali are among the buildings struck in the central area.

The greatest concentration of partially collapsed buildings is noticeable in the area which extends from the Cattedrale to «Largo Fiera».

The bell-tower of the monastery of monache Benedettine, located in the southern part of the town was the only heavily damaged building.

\section{Concluding remarks}

The historical reconstruction of the distribution of effects has emphasized a differentiated seismic response by the urban centre.

Two differently affected areas can actually be identified, clearly located in the southern and northern zones respectively (fig. 6), with an increase in damage from South to North.

The uneven concentration of damage in the urban centre can be attributed to various local factors, such as geology, geomorphology and the different typology of construction.

The reconstruction of macroseismic effects in Isernia can be regarded as the first step toward the definition of a local pattern of interaction between earthquake and territory, and can provide the basis for the construction of a scenario of effects for possible future seismic events.

\section{NOTE}

( $\left.{ }^{1}\right)$ The compilation of a detailed cadastral survey concerning land properties was possible only after the «Unità» of Italy by the L. 3682 March 1, 1886 about the land equalization; so the temporary cadastral survey was effective, in today's province of Isernia, from 1816 - year of establishment - to 1955, when the compilation of Nuovo Catasto Terreni was completed.

\section{Appendix}

The typical expressions used by Fortini (1805-1806) for describing the damage effects of the July 26th, 1805 event are reported. It has been possible to distinguish three different classes of damage: Minor damage, Serious damage and Heavy damage. The letters indicate the monumental buildings, while the numbers are private dwellings as reported in fig. 5 .

Minor damage

Leggiermente lesa

Leso in piccolissima parte

Picciola parte patita

In picciola cosa dannificata

In picciola cosa patito
Danneggiata in picciola parte Molto poco ha patito

D

1

$\mathrm{H}$

11

$15 / 16$
Serious damage

Molto patito

Leso in parte
28

Q

$\mathrm{M} / 9$

$\mathrm{A} / \mathrm{B}$ 


$\begin{array}{ll}\text { Molto dannificato } & \mathrm{C} \\ \text { Alquanto lesionato } & 2 / \mathrm{E} \\ \text { L'è patita } & \mathrm{G} \\ \text { Ha patito molto } & 3 / 4 \\ \text { Molto lesionato } & 5 / 14 \\ \text { Lesionati } & 6 / 7 \\ \text { Molto leso } & 8 \\ \text { Alquanto lesa } & \mathrm{J} \\ \text { Patito di molto } & 12 / 13 / 26 \\ \text { Notabilmente lesionato } & 19 \\ \text { Molto patita } & 20 \\ \text { Considerevolmente lesionato } & 22 / 23 \\ \text { Notabilmente leso } & 24 / 25 \\ \text { Molto lesa } & 27 \\ \text { Patita notabilmente } & 29 \\ \text { Lesionato ma non tanto } & 30 \\ \text { Tutta lesionata } & \mathrm{S} / \mathrm{W}\end{array}$

Heavy damage, partial and total collapse

La torre cascò e schiacciò altre fabbriche

Diroccato perché minacciava ruina $\mathrm{F}$

Moltissimo danneggiato I

Tutta patita 10

Per metà l'è caduto $\quad 17 / 18$

Rovinata quasi tutta 21

Patito considerevolmente, caduta la scalinata

Notabilissimamente patito

Moltissimo patito

La nave di mezzo è tutta caduta; le altre due navi picciole con i pilastri sono considerevolmente patiti, il tetto ruinò

Dannificata moltissimo

32
33
$34 / 35 / 36 / 37$

Sconquassato ed in buona parte gittato a terra

Diroccato in parte 40/41

Quasi tutto è stato devastato, ed il dippiù è inutile

L'è caduto in qualchè parte; il resto generalmente è patito 0

Moltissimo dannificato 43

Quasi tutto abbattuto, ed il resto l'è inservibile

Tutto lesionato, ed in parte caduto 45/46

In parte caduta, ed il restante molto lesionata

Diroccato quasi per un terzo; il dippiù molto malconcio $\quad \mathrm{P}$

Molto patito: il terzo piano diroccato totalmente $\quad 48$

Moltissimo lesionata 49

Non essere abitabile $\quad 50$

Tutto devastato $\quad 51 / 52$

Totalmente rovinato 53

Quasi devastato 54

Tutt'a terra $\quad \mathrm{R}$

Quasi devastata 55

Devastato per la metà $\quad 56$

Sconquassato nella metà $\quad \mathrm{T}$

Tutta caduta U

Devastata V

Nella maggior part'è caduto a terra

$\begin{array}{lll}\text { L } & \text { e nel resto malconcio } & X \\ 31 / \text { unknown }\left({ }^{2}\right) & \text { Ruinata nella facciata; il coro }\end{array}$ l'è patito

Abbattute in buona parte e nel dippiù molto lese

\section{Y}

Diroccato e sconquassato

(1) Casino barone di Sessano.

(2) Palazzo Macioci.

\section{REFERENCES}

Alessio, G., C. Godano, A. Gorini and G.P. Ricciardi (1987): Studio della sequenza sismica del gennaio 1986 presso Isernia, Mem. Soc. Geol. It., 37.

ARChivio di StATO di CAMPOBASSO (1806): Intendenza di Molise.

ARCHIVIO DI StATo DI ISERNIA (1877/1961): Catasto Fabbricati, Isernia.

Archivio di STATo DI ISERnIA (1816/1955): Catasto Provvisorio, Isernia.

ARChIVIO DI STATO DI ISERNIA (1939/1965): Mappe Nuovo Catasto Edilizio Urbano, Isernia.

ARCHIVIO Di STATO DI ISERNIA (1861/1885): Sotto-Prefettura di Isernia, Atti Amministrativi.
ArChivio di STATo DI IsERnia (1809/1865): Stato Civile, Isernia.

ArChivio di Stato di IsERnia (1862/1923): Tribunale, di Isernia, Atti Diversi.

ARChivio DI Stato DI NAPOli Archivio Borbone, vol. 690; Ministero delle Finanze, fasc. 2478 and 2479.

ARCHIVIO STORICO DEL COMUNE DI ISERNIA (1363/1934): Biblioteca Comunale «M. Romano».

BARATTA, M. (1901); I terremoti d'Italia, Ristampa anastatica (Forni Ed. Bologna), 1979.

CAPOZZI, G. (1834): Memoria sul tremuoto avvenuto nel Contado di Molise nella sera de' 26 Luglio dell'anno 1805, Benevento.

Esposito, E., G. Luongo, A. Marturano and S. PorFIDO (1987): Il terremoto di S. Anna del 26 Luglio 1805, Mem. Soc. Geol. It., 37, 171-191. 
Esposito, E., G. Luongo, A. Marturano and S. PorFIDO (1988): I terremoti recenti dal 1980 al 1986 nell'Appennino Meridionale, Mem. Soc. Geol. It., 41, 1117-1128.

Esposito, E., G. Luongo, A. Marturano and S. PorFIDO (1989): Terremoti ed effetti superficiali. Esempi di ricorrenze sistematiche, in Conferenza Scientifica Annuale sulle Attività di Ricerca del Dipartimento, Università di Napoli Federico II - Dip. Geof. e Vulc. (De Frede, Ed., Napoli), 126-127.

Esposito, E., G. LuONGo and S. PORFIDO (1991): Il terremoto del 26 luglio nella diocesi di Caiazzo, in Atti Colloquio sulle Scienze della Terra in Onore di Nicola Covelli - Associazione Storica del Caiatino (Arte Tipografica, Napoli), 95-106.

Esposito, E., G. LuONGO and S. PORFIDo (1991): A new methodology in studying historical seismicity of Southern Apennines (Southern Italy), in Napoli '91, Int. Conf. on Act. Vol. and Risk Mit., Napoli.

Esposito, E., L. Laurelli and S. Porfido (1992): Il terremoto del 26 luglio 1805. Lo scenario dei danni nella città di Isernia, in Atti - Convegno di Studi Interazione Terremoto-Territorio in Provincia di Isernia - Isernia 14 Nov. 1992 (GNDT-CNR, Archivio di Stato di Isernia, Osservatorio Vesuviano), 1-76.

Figliuolo, B. (1988-89): Il terremoto del 1456 (Edizioni Studi Storici Meridionali, Nocera I), 2 vols.

Fortini, P. (1984): Delle cause de' terremoti e loro effetti. Danni di quelli sofferti dalla città di Isernia fino a quello de' 26 luglio 1805, edited by T. SARDELLI (Marinelli Ed.).

Guidoboni, E. (Editor) (1989): I terremoti prima del Mille in Italia e nell'area Mediterranea. Storia archeologia sismologia (SGA, Bologna), pp. 765.

Meletti, C., E. Patacca, P. Scandone and B. FigliuoLO (1988): ll terremoto del 1456 e la sua interpretazione nel quadro sismotettonico dell'Appennino Meridionale, in Il terremoto del 1456 , edited by B. FIGLIUOLO (Edizioni Studi Storici Meridionali, Nocera I.), vol. I, 71-108.

Molin, D. (1985): The Campania earthquake of 990, in Atlas of Isoseismal Maps of Italian Earthquakes, edited by D. PostPISCHL, Quaderni de «La Ricerca Scientifica», 114, 2A, Bologna.

Molin, D. and L. SERVA (1985): The Irpinia earthquake of March 14, 1702, in Atlas of Isoseismal Maps of Italian Earthquakes, edited by D. PosTPISCHL, «Quaderni de "La Ricerca Scientifica», 114, 2A, Bologna.

Molin, D. and E. Guidoboni (1989): Effetto fonti effetto monumenti a Roma: i terremoti dall'antichità a oggi, in I terremoti prima del Mille in Italia e nell'area Mediterranea. Storia archeologia sismologia, edited by E. Guidoboni (SGA, Bologna), pp. 765.

PePE, G. (1806): Ragguaglio Istorico-Fisico del Tremuoto
Accaduto nel Regno di Napoli la sera de' 26 Luglio 1805, Napoli.

Poli, G.S. (1806): Memoria sul tremuoto de' 26 luglio del corrente anno 1805, Napoli.

Porfido, S., E. Esposito, G. LuOngo and A. MartuRANO (1991): Terremoti ed effetti superficiali: esempi nell'Appennino Meridionale, in Atti Centri Abitati Instabili, CNR, Fano, 225-229.

PostPISCHL, D. (Editor) (1985a): Atlas of isoseismal maps of italian earthquakes, Quaderni de «La Ricerca Scientifica», 114, 2A, Bologna.

PostPISCHL, D. (Editor) (1985b): Catalogo dei terremoti italiani dall'anno 1000 al 1980, Quaderni de «La Ricerca Scientifica», 114, 2B, Bologna.

Postpischl, D., A. Branno, E. Esposito, G. Ferrari, A. Marturano, S. Porfido, V. Rinaldis and M. STUCCHI (1985): The Irpinia earthquake of November 23, 1980, in Atlas of Isoseismal Maps of Italian Earthquakes, edited by D. PostPISCHL, Quaderni de «La Ricerca Scientifica», 114, 2A, Bologna.

Serva, L. (1985): The earthquake of June 5, 1688, in Atlas of Isoseismal Maps of Italian Earthquakes, edited by D. POSTPISCHL, Quaderni de "La Ricerca Scientifica», 114, 2A, Bologna.

SPAdEA, M.C., M. Vecchi, P. Gardellini and S. Del MESE (1985): The Molise earthquakes of October 4, 1913, in Atlas of Isoseismal Maps of Italian Earthquakes, edited by D. PostPISCHL, Quaderni de «La Ricerca Scientifica», 114, 2A, Bologna.

SpadeA, M.C., M. VeCCHI, P. Gardellini and S. DeL MESE (1985): The Avezzano earthquakes of January 13, 1915, in Atlas of Isoseismal Maps of Italian Earthquakes, edited by D. POSTPISCHL, Quaderni de "La Ricerca Scientifica», 114, 2A, Bologna.

SpadeA, M.C., M. Vecchi, P. Gardellini and S. DeL MESE (1985): The Irpinia earthquakes of July 23, 1930, in Atlas of Isoseismal Maps of Italian Earthquakes, edited by D. PostPISCHL, Quaderni de «La Ricerca Scientifica», 114, 2A, Bologna.

Spadea, M.C., M. Vecchi, P. Gardellini and S. Del MEsE (1985): The Irpinia earthquakes of August 1962, in Atlas of Isoseismal Maps of Italian Earthquakes, edited by D. PostPIsCHL, Quaderni de «La Ricerca Scientifica», 114, 2A, Bologna.

Stella, A. (1989); Santa Lucia di Serino. Società e terre nei catasti onciario e napoleonico. Santa Lucia di Serino.

Stucchi, M., R. CAmassi and G. MonaChesi (1993) NT: Il catalogo di «lavoro» del GNDT, Rapporto Interno GNDT, pp. 80.

VITI, A. (1972): Note di diplomatica ecclesiastica sulla Contea di Molise dalle fonti delle pergamene capitolari di Isernia, Napoli. 